
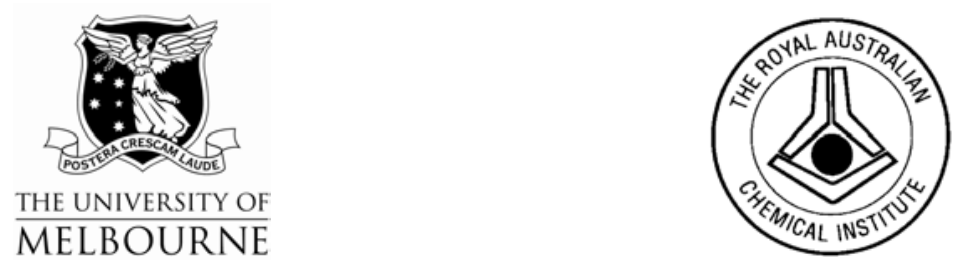

molecules

ISSN 1420-3049

http://www.mdpi.org

Introduction and Guest Editorial

\title{
Melbourne-RACI December Synthesis Symposium
}

\section{Melvyn Gill}

School of Chemistry, The University of Melbourne, Parkville 3010, Victoria, Australia.

Tel.: (+03)-8344-6485, Fax: (+03)-9347-5180, E-mail: melvyn@unimelb.edu.au

Received: 1 January 2004 / Published: 31 May 2004

This special issue of Molecules celebrates the Synthesis Symposium held in The School of Chemistry at the University of Melbourne during the first week of December each and every year since 1976. The Symposium is organized jointly by The School of Chemistry at The University of Melbourne and the Organic Chemistry Group of the Victorian Branch of The Royal Australian Chemical Institute (RACI). This special issue of Molecules contains papers from the Symposia held in 2000, 2001, 2002 and 2003, and I thank the authors for their cooperation and support in putting this issue together. I must also thank our major sponsors Sigma-Aldrich and The RACI Victorian Branch for their long-term financial support and other organizations, including Merck Pty. Ltd., Boron Molecular, Medos, GBC Scientific Equipment, Mettler Toledo, Jomar Diagnostics, Davies Collison Cave, The Australian Journal of Chemistry and CSIRO Molecular Science who, by their involvement, have contributed so much to the continuing success of the Symposium. Professor Emeritus D. W. Cameron has been intimately involved with the Symposium since its inception in 1976 and I am pleased that he has kindly agreed to contribute to this Guest Editorial. 
Shortly after completion of the latest annual Synthesis Symposium (the $28^{\text {th }}$ ) seems a good time to outline some of the features that have led to these meetings being well supported by chemists from the Melbourne area and other parts of Victoria. Perhaps the most important is that successive organising committees have wisely interpreted the title word 'synthesis' so broadly as not to exclude any area of organic, physical-organic or bio-organic chemistry from involvement. And, as one-day events, the symposia hardly represent a heavy time commitment for most would-be participants. So, over the years, there has been a gratifying level of attendance covering local institutions across the board universities, government laboratories and commercial operations. As a result, the meetings now represent probably the most effective local forum for a good cross-section of organic chemists to catch up with one another in person and be made aware of what is going on.

My involvement with the symposia, apart from having attended them all, began early in 1976 when, as departmental Chair, I was asked to help institute them. A colleague, the late Dr Geoff Feutrill, was Secretary of the Victorian RACI Organic Chemistry Group at the time. In consultation with others, he had concluded that the idea of just such an annual event was worth implementing. So did I, though mindful that some enthusiastic beginnings fizzle out quickly for want of organisational staying power. I needn't have worried. Successive Group Committees have done themselves proud in establishing appropriate continuity. The pattern that has emerged has led to parallel meetings being established at other Australian centres, covering at different times Adelaide, Brisbane, Canberra or Sydney, and allowing overseas plenary speakers the opportunity to address a wider audience overall, than would otherwise apply.

Perhaps not surprisingly, successive symposia have witnessed progressive evolution towards covering a wider range of activities. In the early days, the content was all contributed papers. Nowadays, though still forming the core of the programme, contributed papers are generally buttressed at both ends of the day by plenary lectures. There are posters and trade displays, too. Attendances have increased. We used to regard the benchmark figure as around 100 but in recent times have generally been able to count on registrations being nearer 150, sometimes more. Granted, those are not large numbers by the standards of national or international meetings, but they are very substantial in the context of local research chemistry in Australia.

While some such aspects of the symposia have changed, one other, deliberately, has not. There remains a preference for a good proportion of the contributed papers to involve presentation by graduate students, giving many of them the first, encouraging opportunity for describing their work in a serious, though not too daunting, environment. Students and other young chemists make up a considerable proportion of those attending. Whatever uncertainty I might have felt in 1976 as to the longevity of the Synthesis Symposia, the series is now an ongoing Melbourne institution, fulfilling a valuable scientific function. It gives me personal and professional satisfaction to see it so, and I am most grateful to have been afforded the opportunity of contributing to this special issue highlighting some of its recent activities.

Donald W. Cameron 28 Lumeah Road North Caulfield, Vic. 3161 


\section{RACI Synthesis Symposia - Plenary and Invited Speakers 1976-2003}

\begin{tabular}{|c|c|c|}
\hline 1976 & 1st meeting & Short contributed papers \\
\hline 1977 & 2nd & Short contributed papers \\
\hline 1978 & $3 \mathrm{rd}$ & Dr J. E. Pike, Upjohn Company, USA \\
\hline 1979 & 4 th & Professor S. J. Angyal, University of New South Wales \\
\hline 1980 & 5 th & Professor H. Prinzbach, University of Freiburg \\
\hline 1981 & 6 th & Professor W. Steglich, University of Bonn \\
\hline 1982 & 7 th & Professor E. Winterfeldt, University of Hannover \\
\hline 1983 & 8 th & Professor H. Musso, University of Karlsruhe \\
\hline \multirow[t]{2}{*}{1984} & 9 th & Professor M. T. Reetz, University of Marburg \\
\hline & & Professor I. O. Sutherland, University of Liverpool \\
\hline 1985 & 10th & Professor J. Tsuji, Tokyo Institute of Technology \\
\hline \multirow[t]{2}{*}{1986} & 11 th & Professor D. Enders, University of Aachen \\
\hline & & Professor M. C. Whiting, University of Bristol \\
\hline 1987 & 12 th & Professor R. W. Hoffmann, Philipps-University, Marburg \\
\hline \multirow[t]{2}{*}{1988} & 13 th & Professor B. Giese, Technische Hochschule, Darmstadt \\
\hline & & Professor B. Halton, Victoria University of Wellington \\
\hline 1989 & 14 th & Professor G. Bringmann, University of Wurzburg \\
\hline \multirow[t]{3}{*}{1990} & 15 th & Professor G. Helmchen, University of Heidelberg \\
\hline & & Professor H. Alper, University of Ottowa \\
\hline & & Professor A. R. Battersby, University of Cambridge \\
\hline \multirow[t]{2}{*}{1991} & 16th & Professor H. Hopf, University of Braunschweig \\
\hline & & Professor W. A. Denny, University of Auckland \\
\hline \multirow[t]{2}{*}{1992} & 17 th & Professor H.-U. Reissig, TechniecheHochscule, Darrmstadt \\
\hline & & Dr. M. G. Banwell, University of Melbourne \\
\hline \multirow[t]{2}{*}{1993} & 18 th & Professor H. Kesler, Technical University of Munich \\
\hline & & Professor R. A. Russell, Deakin University \\
\hline \multirow[t]{2}{*}{1994} & 19 th & Professor J. Mulzer, Free University of Berlin \\
\hline & & Professor L. Hegedus, Colorado State University \\
\hline \multirow[t]{2}{*}{1995} & 20 th & Professor A. Brossi, NIH and The University of North Carolina \\
\hline & & Professor D. W. Cameron, University of Melbourne \\
\hline \multirow[t]{3}{*}{1996} & $21 \mathrm{st}$ & Professor P. Wipf, University of Pittsburgh \\
\hline & & Professor I. Ojima, State University of New York at Stony Brook \\
\hline & & Dr F. J. Leeper, University of Cambridge \\
\hline \multirow[t]{2}{*}{1997} & 22nd & Dr I. Patterson, University of Cambridge \\
\hline & & Professor K. Feldman, The Pennsylvania State University \\
\hline \multirow[t]{2}{*}{1998} & $23 \mathrm{rd}$ & Professor S. M. Weinreb, The Pennsylvania State University \\
\hline & & Professor N. Miyaura, Hokkaido University \\
\hline
\end{tabular}




\begin{tabular}{|c|c|c|}
\hline 1999 & 24th & Professor G. Molander, University of Pennsylvania \\
\hline & & Professor C. Chatgilialogu, Consiglio Nazionale delle Richerche, Bologna \\
\hline 2000 & 25th & Professor D. P. Curran, University of Pittsburgh \\
\hline & & Professor P. J. Steel, University of Canterbury \\
\hline & & Professor C. Forsyth, University of Minnesota \\
\hline 2001 & 26th & Professor S. Kim, Korea Advanced Institute of Science and \\
\hline & & Technology, Taejon \\
\hline & & Professor A. Ganesan, University of Southampton \\
\hline 2002 & 27 th & Professor M. A. Brimble, University of Auckland \\
\hline & & Professor M. G. Banwell, Australian National University \\
\hline 2003 & 28th & Professor P. Renaud, University of Bern \\
\hline & & Dr J. Palmer, Celera Genomics, San Francisco \\
\hline
\end{tabular}

Melvyn Gill, PhD, DSc (Brad), FRACI, FRSC, CChem.

2004 by MDPI (http://www.mdpi.org). Reproduction is permitted for noncommercial purposes. 